\title{
Perbandingan Kandungan Serat Kasar Selai Cempedak yang Diperam Secara Tradisional dan Menggunakan Karbid
}

\author{
Dwi Nur Aini Dahlan \\ Fakultas Tarbiyah dan Ilmu Keguruan \\ IAIN Samarinda, Indonesia \\ ai3_nii@yahoo.com
}

\begin{abstract}
ABSTRAK
Buah cempedak merupakan salah satu buah yang banyak mengandung serat makanan. Teknologi pemeraman buah cempedak diduga memiliki dampak terhadap kandungan serat kasar terutama ketika diolah menjadi selai. Penelitian ini bertujuan untuk mengetahui jenis pemeraman yang tepat untuk menghasilkan selai cempedak yang mengandung serat kasar positif untuk mendapatkan mutu terbaik selai cempedak. Analisis data menggunakan uji One Way Anava dengan bantuan SPSS statistic 21. Hasil penelitian menunjukkan adanya perbedaan yang nyata dengan nilai signifikansi 0.55 pada kandungan serat kasar antara selai cempedak yang diperam secara tradisional dengan cempedak yang diperam dengan menggunakan karbit. Kandungan serat kasar selai cempedak yang diperam secara tradisional (nilai rata-rata: 0.75) lebih tinggi dibandingkan selai cempedak yang diperam dengan menggunakan karbit (nilai rata-rata: 0.49 )
\end{abstract}

Kata kunci : Serat Kasar, Serat Kasar Selai, Selai Cempedak, Pemeraman Buah

\begin{abstract}
One of the fruits that contain lots of crude fiber is cempedak fruit. Cempedak fruit ripening technology that has an impact on crude fiber content, especially when processed into jam. This research aims to determine the right type of ripening to produce cempedak jam containing positive crude fiber to get the best quality cempedak jam. Data analysis used was the One Way Anava test with the application of SPSS statistics 21. The results showed a significant difference with a significance value of 0.55 in the crude fiber content between cempedak jam traditionally ripened with cempedak whose ripening used carbide. Crude fiber content in cempedak jam traditionally ripened (average value: 0.75) higher than cempedak jam which is ripened using carbide (average value: 0.49 )
\end{abstract}

Keyword: Crude Fiber, Crude Fiber Jam, Cempedak Jam, Fruit Ripening

\section{PENDAHULUAN}

Serat kasar merupakan senyawa yang oleh alkali atau asam tidak mampu terhidrolisis. Dalam penilaian kualitas bahan makanan serat kasar sangat penting karena dapat dijadikan sebagai penentu nilai gizi makanan tersebut (AACC, 2001). Indeks kadar serat makanan dalam 
suatu makanan adalah serat kasar, karena dalam serat kasar pada umumnya didapatkan sebesar 0.2-0.5 bagian dari jumlah serat makanan. Enzim enzim pencernaan tidak dapat menghidrolisis bagian dari bahan yaitu serat makanan (Pilliang dan djojosoebagio, 2002).

Serat memiliki peranan penting dalam sebuah makanan karena dapat mencegah penyerapan zat-zat gizi seperti lemak, protein, dan karbohidrat. Makanan yang memiliki kandungan serat kasar rendah maka zat-zat gizi makanan dalam tubuh hampir semua dapat diserapnya. Bila kandungan serat makanan dalam makanan tersebut tinggi maka orang akan mengunyah lebih lama sehingga serat tersebut dapat mempercepat rasa kenyang. Penyakit yang dapat dicegah oleh serat terdapat beberapa jenis antara lain wasir, sembelit, gangguan usus, diabetes, kegemukan, kadar kolestrol dan jantung koroner, kanker dan daya tahan tubuh. Banyaknya manfaat pada serat menjadikan serat kasar harus ada pada makanan untuk meningkatkan mutu makanan tersebut. Serat kasar banyak ditemukan di buah-buahan yang salah satunya merupakan buah cempedak (Harland, 2001).

Artocarpus champaden Lour atau Buah cempedak adalah salah satu buah yang mengandung serat kasar. Leong dan Sui (2002) dalam hasil penelitiannya dijelaskan bahwa kandungan anti oksidan dalam buah cempedak sebanyak 126 $\pm 19,1 \mathrm{mg} / 100 \mathrm{~g}$. Dalam setiap 100 gram yang dapat dimakan dari bagian buah cempedak kira-kira memiliki kandungan yaitu lemak 0,4 gram, protein 3,0 gram, karbohidrat 28,6 gram, fosfor $30 \mathrm{mg}$, kalsium $20 \mathrm{mg}$, zat besi 1,5 mg, vitamin C 15 mg, vitamin A 200 SI, air 67,0 g, dan nilai energi yang terkandung sebesar 116 kkal (Astawan, 2009). Cempedak adalah tanaman buah tropik yang termasuk dalam famili Moraceae dan yang mempunyai nilai ekonomi tinggi. Buah cempedak memiliki kandungan gizi yang cukup tinggi serta aroma, rasa dan juga bentuk yang khas (Tetty, 2011). Buah cempedak juga termasuk ke dalam kelompok buah klimaterik.

Banyaknya masyarakat yang menjadi peminat buah cempedak menyebabkan buah cempedak menjadi buah primadona. Olahan makanan yang berbahan dasar buah cempedakpun ikut diminati oleh masyarakat. Salah satu olahan cempedak yang masih perlu dianalisis lebih lanjut adalah selai. Selai adalah produk olahan makanan dengan tekstur semi padat yang campurannya terbuat dari buah dan gula. Tujuan pengolahan selai adalah untuk peningkatan aneka ragam produk, masa simpan lebih panjang, dan bertambahnya nilai ekonomis (Andreas, 2017). Prosedur dalam pembuatan selai merupakan proses yang rumit dengan sejumlah variabel untuk mengoptimalkan produk akhir. Berdasarkan SII. No. 173 standard syarat mutu selai diantaranya 
adalah maksimum 35\% kadar air, minimum 0,5\% padatan tak terlarut, maksimum 0,7\% kadar pektin, maksimum 55\% kadar gula, $50 \mathrm{mg} / \mathrm{kg}$ kadar bahan pengawet, asam asetat negatif, serat buah positif, logam berbahaya (Hg, Pb, As) negatif, bau normal, dan rasa normal (SNI, 2008).

Karena pada buah yang masih muda memiliki kandungan pectin rendah sehingga tidak dapat digunakan untuk pembuatan selai (Sidauruk, 2011). Kriteria dalam pembuatan selai ialah dengan menggunakan buah dengan tingkat kematangan yaitu buah yang tidak ada tanda-tanda busuk, masak, kandungan asam dan pektin cukup dalam menghasilkan produk selai terbaik. (Septi, 2014). Pematangan buah dapat diperoleh dengan dua cara yaitu secara alami (tradisional) dan bantuan manusia (dengan penambahan pemicu pematangan buah). Pematangan buah yang dibantu dengan manusia salah satunya adalah metode pemeraman.

Pemeraman dalam hortikultura adalah perlakuan sengaja oleh manusia dalam proses pematangan buah agar lebih cepat dengan cara buah yang telah dipetik pada massa panen tertentu disimpan dalam tempat yang relatif tertutup. Pemeraman dapat dilakukan agar pematangan buahnya lebih cepat hanya pada kelompok buah klimakterik (Tim Penulis PS, 1998). Karena termasuk dalam buah klimaterik maka buah cempedak bisa dipanen ketika kondisi buah masih mentah dan disimpan dengan kondisi tertentu agar matang. Untuk memenuhi kebutuhan dalam jumlah besar akan buah cempedak maka dalam menyeragamkan kematangan buah diperlukan teknologi pemeraman.

Menurut Kaleka (2013) proses fisiologi pada buah masih melangsungkan dengan adanya karbon dioksida dan gas etilen dalam jumlah yang meningkat hingga proses pematangan buah terjadi meskipun buah tersebut belum matang saat dipanen. Pemeraman buah buahan terdapat berbagai macam yang telah diaplikasikan pada umumnya adalah cara tradisional yaitu dengan memakai daun, perlukaan maupun dibiarkan dan non tradisional dengan menggunakan karbit. 1 gram $\mathrm{CaC}$ menghasilkan $349 \mathrm{ml}$ asetilen yang akan dipakai dalam proses pemeraman yaitu dengan mengganti etilen yang oleh buah-buahan dihasilkan secara langsung (Suryanegara, 2012). Pematangan dengan menggunakan karbid cenderung lebih cepat dibandingan dengan bahan lainnya (Arif, et al, 2014) Selain itu, pemeraman cempedak menggunakan karbid lebih memiliki warna dan tekstur yang menarik daripada selai cempedak yang diperam secara tradisional. Pemeraman secara tradisional lebih unggul rasa dan warna selai cempedak yang dihasilkan daripada yang diperam dengan menggunakan karbid (Dahlan, 2018). 
Berdasarkan uraian di tersebut, maka perlu dilakukan perbandingan lebih lanjut dalam melakukan pemeraman buah cempedak. Hal ini sangat menentukan kualitas selai cempedak sebelum produksi dalam jumlah besar. Dengan demikian tujuan penelitian ini adalah mengetahui jenis pemeraman yang tepat untuk menghasilkan selai cempedak yang mengandung serat kasar.

\section{METODE PENELITIAN}

Pembuatan selai cempedak dilakukan dengan beberapa tahapan, yakni buah cempedak dikupas, dicuci kemudian ditimbang $100 \mathrm{~g}, 10 \mathrm{~g}$ gula pasir, dan asam sitrat 0,1 g, selanjutnya daging buah cempedak diblanching dengan suhu $60-80^{\circ} \mathrm{C}$ selama 5 menit kemudian dipotong kecil- kecil dan diblender halus. Setelah dihaluskan, kemudian dimasak pada wajan dan ditambahkan gula pasir. ketika proses memasak, bubur cempedak terus-menerus diaduk sampai warnanya berubah menjadi coklat dan teksturnya menjadi kental dan. Setelah berwarna cokelat, adonan cempedak diberi asam sitrat (1 g) dan diaduk hingga merata. Setelah kental kemudian selai cempedak didinginkan dan dimasukkan ke dalam botol yang sudah disterilkan. Analisis data yang didapatkan akan memakai uji One Way Anava. Pengujian dibantu dengan aplikasi SPSS statistic 21 .

\section{HASIL DAN PEMBAHASAN}

Untuk melihat pengaruh pemeraman buah cempedak terhadap kandungan serat kasar, maka dilakukan uji normalitas. Uji distribusi normalitas dapat dilihat pada Tabel 1.

Tabel 1. Uji Distribusi Normalitas Kandungan Serat Kasar

\begin{tabular}{|c|c|c|c|c|c|c|c|}
\hline & \multirow[t]{2}{*}{ jenis pemeraman } & \multicolumn{3}{|c|}{ Kolmogorov-Smirnov $^{\mathrm{a}}$} & \multicolumn{3}{|c|}{ Shapiro-Wilk } \\
\hline & & Statistic & $\mathrm{df}$ & Sig. & Statistic & Df & Sig. \\
\hline \multirow{2}{*}{ Serat kasar } & Karbit & .175 & 3 & & 1.000 & & 1.000 \\
\hline & Tradisional & .238 & 3 & & .976 & & .702 \\
\hline
\end{tabular}


Hasil statistika dengan menggunakan SPSS menunjukkan bahwa nilai signifikansi jenis pemeraman tradisional 1 sedangkan kelompok jenis pemeraman tradisional 0,976. Hal tersebut menunjukkan bahwa nilai signifikansi lebih besar dari 0,05 yang artinya data bedistribusi normal. Berdasarkan hasil yang telah diperoleh maka dapat dilakukan uji homogenitas yakni untuk melihat varian data. Uji varian data dapat dilihat pada tabel 2.

Tabel 2. Uji Varian Data Kandungan Serat Kasar Pada Selai Cempedak

\begin{tabular}{cccc}
\hline $\begin{array}{c}\text { Levene } \\
\text { Statistic }\end{array}$ & $\begin{array}{c}\text { df } \\
1\end{array}$ & df2 & Sig. \\
\hline 6.084 & 1 & 4 & .069 \\
\hline
\end{tabular}

Nilai signifikansi menunjukkan bahwa nilai signifikansi varian data 0,69 sehingga nilai signifikansi varian data lebih besar dari 0,05. Sehingga dapat dipastikan bahwa varian ke dua kelompok pemeraman secara tradisional dan pemeraman dengan karbit adalah sama sehingga asumsi uji homogenitas telah terpenuhi untuk one way anava. pengujian one way ANOVA diaplikasikan untuk melihat perbedaan jenis pemeraman pada kandungan serat kasar pada selai. Uji one way ANOVA yang diaplikasikan didapatkan hasil seperti pada tabel 3.

Tabel 3. Uji Anava Kandungan Serat Kasar Pada Selai Cempedak

\begin{tabular}{|l|r|r|r|r|r|}
\hline & Sum of Squares & df & Mean Square & F & Sig. \\
\hline Between Groups & .101 & 1 & .101 & 7.243 & .055 \\
Within Groups & .056 & 4 & .014 & & \\
Total & .157 & 5 & & & \\
\hline
\end{tabular}

Hasil analisis statisk ANAVA menunjukkan bahwa nilai signifikansi sebesar 0,055. Hal tersebut menunjukkan bahwa nilai signifikansi lebih kecil dari 0,05 yang berarti Ho diterima. Uji statistik tersebut berarti menunjukkan tidak terdapat perbedaan yang nyata pada kandungan serat kasar selai cempedak antara cempedak yang diperam secara tradisional dengan cempedak yang diperam dengan menggunakan karbit. Rata-rata kandungan serat kasar pada selai cempedak dapat dilihat pada Gambar 1. 
Gambar 1. nilai rata-rata setiap ulangan pada kandungan serat kasar pada selai cempedak

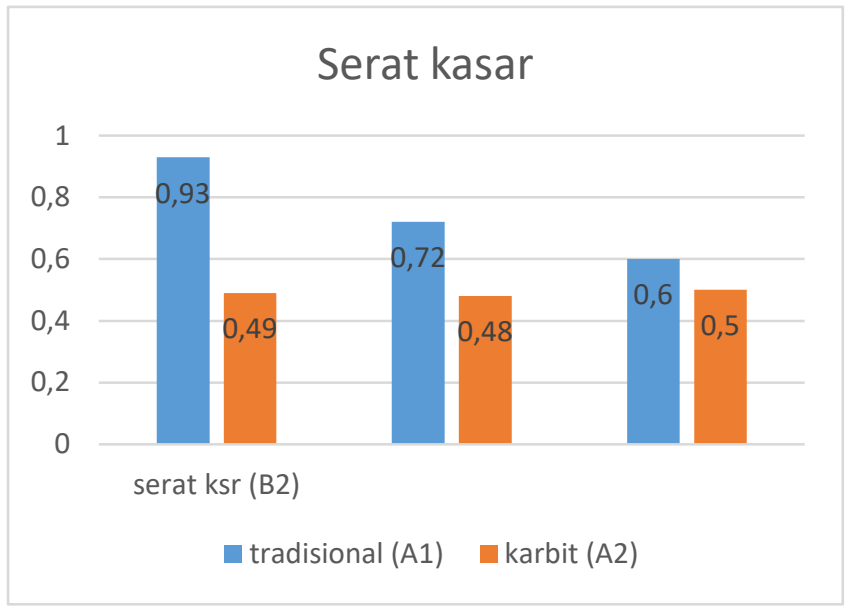

Gambar tersebut menunjukkan bahwa kandungan serat kasar selai cempedak yang cempedaknya diperam secara tradisional didapatkan nilai ulangan 1: 0.93 ulangan II: 0.72 dan ulangan III: 0.6. Nilai total dari keseluruhan serat kasar dari seluruh ulangan adalah 2.25 dengan nilai rata-rata 0.75 . Selai cempedak yang cempedaknya diperam dengan menggunakan karbit didapatkan nilai ulangan 1: 0.49 ulangan II: 0.48 dan ulangan III: 0.5. Nilai total dari keseluruhan serat kasar dari seluruh ulangan adalah 1.47 dengan nilai ratarata 0.49. Dengan demikian nilai kandungan serat kasar pada selai cempedak secara rata-rata lebih besar cempedak yang diperam dengan menggunakan tradisional daripada cempedak yang diperam menggunakan karbit.

Hasil penelitian secara keseluruhan menunjukkan adanya serat kasar pada selai cempedak dengan konsentrasi yang berbeda. Hal ini menunjukkan bahwa mutu selai cempedak dapat memenuhi standar minimal kualitas selai cempedak seperti yang telah tercantum pada SII NO.137 TH 1978 bahwa serat kasar harus berindikasi positif. Dalam serat kasar terkandung beberapa hemiselulosa, selulosa, dan polisakarida lain yang memiliki fungsi sebagai bahan pelindung bagi tanaman. Dalam serat kasar juga terdapat kandungan lignin yang terdapat di beberapa tanaman utamanya pada bagian biji dan kulit buah (Winarno, 2002)

Meningginya aktivitas enzim hemiselulosa dan selulosa selama proses berlangsungnya pemeraman menyebabkan penurunan serat kasar. Suhu panas yang dihasilkan karbit dalam memproduksi hormon ethilen menyebabkan menurunnya ph pada buah. Menurut Sapienza dan bolsen bahwa meningkatnya kecepatan hidrolisis beberapa polisakarida seperti hemiselulosa secara kimiawi karena penurunan pH dapat menurunkan kadar serat kasa (Bolsen \& Sapienza, 1993). Menurut Anggorodi (1984) bahwa selulosa yang terombak merupakan salah satu 
komponen dari serat kasar maka enzim seperti lignin, selulosa, dan hemiselulosa yang terkandung dalam serat kasar menjadi rendah.

Selain hal tersebut penyebab lebih rendahnya serat kasar pada pemeraman dengan menggunakan karbit juga karena adanya reaksi maillard. Reaksi maillard pada umumnya disebut juga reaksi browning. Reaksi gula dengan asam amino dengan pelepasan panas dan pembentukan molekul-molekul besar yang susah dicerna. Laju reaksi kimia akan lambat apabila temperatur dibawah $60^{\circ} \mathrm{c}$. Akan tetapi dengan naiknya temperatur maka laju reaksi maillard akan bertambah sering (Ratnakomala, et al, 2006).

Adanya penurunan kadar serat kasar pada cempedak yang diperam dengan menggunakan karbit mempengaruhi tekstur dari selai. cempedak yang diperam dengan menggunakan karbit memiliki tekstur lebih menarik dan mudah untuk mengambilnya karena tisak berserat. Hal ini sejalan dengan penelitian yang dilakukan oleh Dahlan (2018) bahwa tekstur selai cempedak yang diperam dengan menggunakan karbit lebih lunak dan banyak diminati oleh panelis.

\section{SIMPULAN}

Berdasarkan pada pembahasan dan analisis yang telah dilakukan, maka dapat diambil kesimpulan bahwa ada perbedaan yang nyata dengan nilai signifikansi 0.55 pada kandungan serat kasar antara selai cempedak yang diperam secara tradisional dengan cempedak yang diperam dengan menggunakan karbit. Kandungan serat kasar selai cempedak yang diperam secara tradisional (nilai rata-rata: 0.75) lebih tinggi dibandingkan selai cempedak yang diperam dengan menggunakan karbit (nilai rata-rata: 0.49)

\section{DAFTAR PUSTAKA}

AACC. 2001. The Definition of Dietary Fiber. Cereal Fds. World.

Andreas pandiangan, Faizah Hamzah dan Rahmayuni, 2017, pembuatan selai campuran buah pepaya dan buah terung belanda. Jom fakultas pertanian, volume 4 no 2 . Riau

Arif, A.B., Wahyu D, Enrico S, Suyanti dan Setyadjit. 2014. Optimization of Ripening Technology in Cempedak Fruit (Artocarpus champeden). Journal infromatika pertanian. Vol 23 no 1 juni 2014: 35-46.

Arifin, H., Delvita, V., Almahdy, 2007, Pengaruh Pemberian Vitamin C Terhadap Fetus Mencit Diabetes, Jurnal Sains dan Teknologi Farmasi, 12(1), 32-40. 
Dahlan, DNA. 2018. The Influence of Cempedak (Artocarpus champaden Lour.) Ripening Variation on Organoleptic Properties of Jam Produced. Int. J. Curr. Res. Biosci. Plant Biol. (2018) 5(6), 58-65.

Englberger, L., Schierle, J., Kraemer, K., Aalbersberg, W., Dolodolotawake, U., Humphries, J., Graham, R., Reid, A. P., Lorens, A., Albert, K., Levendusky, A., Johnson, E., Paul, Y., Sengebau, F., 2008, Carotenoid and mineral content of Micronesian giant swamp taro (Cyrtosperma) cultivars, JFCA, 21, 93-106.

Harland, B.F. and D. Oberleas. 2001. Effects of Dietary Fiber and Phytate on the Homeostasis and Bioavailability of Minerals. CRC Handbook of Dietary Fiber in Human Nutrition, $3^{\text {rd }}$ Ed,G.A. Spiller, ed.,CRC Press, Boca Raton. 2001.

Heriyanto, 2009, Karotenoid (Beta-karoten), (online), (http://repository.usu.ac.id/ bitstream/123456789/20091/4/k arotenoid(beta-karoten).pdf.

Hock-Eng, K., Prasad, K. N., Kin-Weng, K., Jiang Y., dan Ismail, A., 2011, Carotenoids and Their Isomers: Color Pigments in Fruits and Vegetables, J. Molc., 16, 1710- 1738.

Kaleka, N. 2013. Commercial Bananas. Arcita Publisher. Surakarta. first edition.

Leong L. P dan G. Shui. 2002. An Investigation Of Antioxsidant Capacity of Fruit in Singapore Markets. Food Chemistry. 76: 69-75.

Lubis Z, Ikhwal A, dan Ginting S. 2014. Pengaruh Konsentrasi Pektin dan lama penyimpanan terhadap mutu selai nanas lembaran. Jurnal rekayasa pangan dan pertanian. Vol 4 no 4 tahun 2014.

Nair,S. dan Z. Singh, 2003. Pre-storage ethrel dip reduces chilling injury enhances respiration rate, ethylene produsction and improves fruit quality of „Kensington ${ }^{\text {ee }}$ mango. Food, Agriculture \& Environment.1(2) : 93-97.

Ottaway, P.B. 1999. The Technology of Vitamins in Food. Aspen Publisher, Inc. Garthersburg. Marryland.

Parwata, O.A., Ratnayani, K., Listya, A. 2010. Aktivitas antiradikal bebas serta kadar betakaroten pada madu randu(Ceiba pentandra) dan madu kelengkeng (Nephelium Longata L) jurnal Kimia 4 vol 1 januari 2010:54-62. ISSN 1907-9850.

Piliang, W.G. dan S. Djojosoebagio, Al Haj. 2002. Fisiologi Nutrisi. Vol. I. Edisi Ke-4. IPB

Risti Febriani, Kapti Rahayu Kuswanto, Linda Kurniawat. (2018) Karakteristik Selai Fungsional Yang Dibuat Dari Rasio Buah Naga Merah (Hylocereus Polyhizus)-Jambu Biji Merah (Psidium Guajava)-Nanas Madu (Ananas comosus) Dengan Variasi Penambahan Gula. Fakultas Teknologi dan Industri Pangan Universitas Slamet Riyadi Surakarta. 
Septi, E.D. 2014. Perbandingan Kadar Vitamin C , Organoleptik dan Daya Simpan Selai Buah Tomat (Lycopersicum wsculentum) dan Pepaya (Carica papaya) yang ditambahkan Gula Pasir. Fakultas Keguruan dan Ilmu Pendidikan Universitas Muhammadiyah Surakarta.

Sidauruk, M. 2011. Studi pembuatan selai campuran dami nangka (Artocarpus heterophyllus) dengan belimbing wuluh (Averrhoa blimbi L). Skripsi. Fakultas Pertanian, Universitas Padang.

SNI. 2008. Selai buah. SNI 374: 2008. Jakarta: BADAN STANDARISASI NASIONAL.

Subawati, Reni Kusumaningtyas dan Leenawaty Limantara, 2009, Isomerisasi dan Oksidasi Senyawa Karotenoid dalam Buah Kelapa Sawit Selama Pengolahan CPO, Indonesian Journal of Chemistry, Vol 9 No 1: $48-53$

Suryanegara, 2012. Traditional Fruit Diving Using Gamal Leaf (Glircidia Maculata), Dapdap, Gerombong And Carbit. http://wayansuryanegara.blogspot.co.id/2012/04/pengeraman-buahsecara tradisional.html. accessed on 20 March 2018

Tetty, NAH. 2011. The influence of comparative concentration of sucrose and cempedak juice (artocarpus integer (tunb.) Merr.) On quality of candy jelly during on storage periode (Essay). Faculty of Technobiology of Biology Program. Atma Jaya University Yogyakarta

Tim penulis PS. 1998. Agribusiness of Fruit Plants. Jakarta: Niaga Swadaya. ISBN 97948919.

Winarno, F.G., Fardiaz. S dan Fardiaz, D. 2002. Pengantar teknologi pangan. Jakarta. PT gramedia.

Winarno, FG. 2002. Kimia pangan dan gizi. Jakarta: Gramedia 